\title{
Environmental Assessment for Soils and Plants Irrigated From Canal Bani Ghalib Assiut Governorate Egypt
}

\author{
Sherif A.E.A. \\ Environmental Research Department, Soils, Water and Environment Research Institute, Agric. Res. \\ Center, Giza, Egypt.
}

$$
\text { Received: } 05 \text { August 2019/ Accepted 30 Sept. 2019/ Publication date: } 30 \text { Oct. } 2019
$$

\begin{abstract}
Irrigation water always carry substances derived from its natural environment or from the waste products of different activities (domestic and industrial effluents). The present study was carried out on Bani Ghalib canal, Assiut Governorate, Egypt to assess the environmental risks of inorganic pollutants and microbial pollutants to be introduced in soil and some vegetable and crop irrigated from this canal. Canal water, soil and plant samples were collected from different sites along canal during winter and summer seasons of 2017. The obtained results indicated that, all macro, micro elements and heavy metal concentrations under study in water samples were below permissible limits. In both winter and summer seasons available $\mathrm{Fe}, \mathrm{Mn}, \mathrm{Zn}, \mathrm{Cu} \mathrm{Pb}$ in soils were higher than the permissible limits; while $\mathrm{Cd}$, Co and $\mathrm{Cr}$ were lower permissible limits; available $\mathrm{B}$ and $\mathrm{Ni}$ were moderate concentration. The content of elements in different plants were high for $\mathrm{Fe}, \mathrm{Cr}$ and $\mathrm{Co}$; moderate for $\mathrm{Mn}$; moderate to high for $\mathrm{Zn}, \mathrm{Cu}$ and $\mathrm{Ni}$; while were low for $\mathrm{B}, \mathrm{Cd}$ and $\mathrm{Pb}$.-Concerning, (TSS), (COD) and (BOD) $\left(\mathrm{mgL}^{-1}\right)$ in water and total coliform, fecal coliform and salmonella \& shigella in water and soil were higher than permissible limits; Also, plant microbial contamination was above allowable limits, which could cause a lot of diseases to humans. Contamination factor was very high for Cd. Degree of contamination was moderate to high in all sites. Modified degree of contamination suggested that low degree in all sites at winter season except Menkab site while in summer season was low degree of contamination at Madabegh and Hadaia sites. The values of Pollution lod index were found to be generally $(\mathrm{PLI}<1)$ in all sites except Mangabad site in winter. Enrichment factor was low values for each of $\mathrm{Mn}, \mathrm{Zn}, \mathrm{B}, \mathrm{Co}, \mathrm{Cr}, \mathrm{Ni}$ and $\mathrm{Pb}$ in all sites at two seasons, except $\mathrm{Mn}, \mathrm{Cr}$ and $\mathrm{Ni}$ at $\mathrm{Al}$ Hadaya site in winter season; $\mathrm{Cr}$ and $\mathrm{Ni}$ in summer season were moderate; while $\mathrm{Cd}$ was high to very high at different sites. The bio-concentration factor was very high $(>1)$ for all plants grown in the soil affected by irrigation water; which considered hyper-accumulator for ( $\mathrm{Fe}$, $\mathrm{Mn}, \mathrm{Zn}, \mathrm{Cu}, \mathrm{B}, \mathrm{Cd}, \mathrm{Co} \mathrm{Cr}$ and $\mathrm{Ni}$ ) at winter and summer seasons. Regard to (BCF), the for $\mathrm{Pb}$ was less than 1 for Alfa Alfa, Cabbage, Onion, Elephant forage, Eggplant and BCF (>1) at Wheat, Garlic, Arugula, Okra and Maize plants.
\end{abstract}

Keywords: Environment, Risk assessment, Pathogenic, Heavy metals, Pollution.

\section{Introduction}

Irrigated lands contribute significantly to global agriculture output and food supply (Abdel Kawy et al. 2013). The quality of irrigation water directly influences the quality of the soil and the crops grown on this soil. Poor irrigation water quality has a negative effect on crop productivity, crop product quality, and public health of consumers and the farmers who come in direct contact with the irrigation water (Qadir et al. 2007; Listkas et al. 2010 and Muthanna 2011). The suitability of water for agricultural purposes can be determined by an evaluation of some physico-chemical parameters along with some calculated hydro geochemical applications (Rouabhia et al. 2010). Contamination with heavy metals is one of the most serious problems in the aquatic environments. The disposal of municipal pollutes, the enhancement of industrial activities led to an increase in heavy metals and pathogenic in the environment (water, soil and plant), (El-Kassas et al. 1994).

There are certain heavy metals such as $\mathrm{As}, \mathrm{Cd}, \mathrm{Cu}, \mathrm{Pb}, \mathrm{Ni}$ and $\mathrm{Zn}$ are common pollutants and came from different natural and anthropogenic sources. Rawway et al. (2016) examine the bacterial quality of water at Assiut Governorate around the Nile River, by determination of total bacterial counts as well as bacterial indicators (total Coliform, fecal Coliform, and fecal Streptococci), He

Corresponding Author: Sherif A.E.A., Environmental Research Department, Soils, Water and Environment Research Institute, Agric. Res. Center, Giza, Egypt.

E-mail: Abd_hamid6@yahoo.com 
found that all of samples were contaminated with (total Coliforms, fecal Coliforms and fecal Streptococci).

Sayeda et al. (2011) studied the total bacterial load of the Nile water for four seasons of the year and she found that the seasonal effect was distinguishable, the total microbial load of various bacterial groups being statistically highest in autumn and lowest in winter. The ratio of fecal coliforms to fecal streptococci ranged from 0.04 to 16.4. Otherwise, the ratio was very variable, indicating the complexity of the pollution sources, being a mixture of both human and non-human (0.9-3.4). Distinctive cases of human sources of pollution (12.3-16.4) were distinguishable in spring. The chemical parameters ( $\mathrm{pH}, \mathrm{EC}$, TDS and alkalinity) were increased $(3-9 \%)$ by the effluent disposal. The effluent did positively increase both BOD (20\%) and COD (8\%) at the disposal site, then progressively decreased downstream.

Esmat, (2019) found that the average heavy metals content in the studied cultivated soils was above the acceptable levels. Abou El-Anwar et al. (2019) studied the suitability for soils affected by El-Madabgh sewage station and many big industries; cement, fertilizers, and pharmaceutical for cultivation at Assiut Governorate. The results pointed to the mixed source (geogenic and anthropogenic) of $\mathrm{Fe}, \mathrm{Co}, \mathrm{Cu}, \mathrm{Ni}, \mathrm{Zn}, \mathrm{Zr}$, and $\mathrm{Cr}$ and the anthropogenic source of $\mathrm{As}, \mathrm{Pb}$, and $\mathrm{Cd}$ (especially phosphatic fertilizers) in the soil. The chemical properties of soil affected mainly by the agricultural practices (application of fertilizers, pesticides, manure, and wastewater irrigation), industrial inputs, and atmospheric deposition. Alsayed and Negim (2018) found that, the soils of Arab-El-Madabegh village, Assiut Governorate, Egypt; were contaminated by heavy metals. Zinc, $\mathrm{Cu}, \mathrm{Pb}, \mathrm{Cd}$ and $\mathrm{Ni}$ concentrations in the edible portions of the studied vegetables plant ranged between $75-110,15-17,2-5,1.0-3.5$ and $1.0-2.5 \mathrm{mg} \mathrm{kg}^{-1}$, respectively. Esawy and Adel (2016) calculate the bioaccumulation factors for $\mathrm{Cd}, \mathrm{Pb}, \mathrm{Zn}, \mathrm{Cu}$, and $\mathrm{Mn}$ in maize shoots grown in soils irrigated by contaminated water from Zefta drain and drain no. 5, it was higher than 1.0 and exceeded the upper limit of background heavy metals.

Mekky et al. (2019) studied the assessment of potential risks of $\mathrm{As}, \mathrm{Cd}, \mathrm{Co}, \mathrm{Cr}, \mathrm{Cu}, \mathrm{Ni}, \mathrm{Pb}$, and $\mathrm{Zn}$ in soils using pollution indices; Enrichment Factor (EF), Contamination Factor (CF), Degree of Contamination (Cd), Pollution Load Index (PLI). He found that PLI can considered generally moderately polluted. The average concentrations of $\mathrm{Pb}, \mathrm{Cd}$, and $\mathrm{Zn}$ were $38.2,2.3$, and $43.4 \mu \mathrm{g} \mathrm{g}^{-1}$, respectively. The bioavailable fraction (EDTA-Extract) was 72.5 and $37.5 \%$ for $\mathrm{Pb}$ and $\mathrm{Cd}$ contents, respectively.

The aim of the current study is to obtain accurate information related to the quality of irrigation water along the Bani Ghalib irrigation canal-Assiut Governorate where significant changes of hazard of salinity, metals and biological aspects and to predict the risk associated with the unrestricted using water polluted with municipal waste for irrigation and its effect on soil and field crops grown at different sites.

\section{Material and Methods}

\section{Description of the study area:}

Assiut Governorate is one of the oldest and largest Governorates in Upper Egypt, with a total area of $25,926 \mathrm{~km}^{2}$ and is located on both banks of the Nile.

The study was conducted at Bani Ghalib canal (which receive municipal water from different sources) during two growing season of 2017 according to the complains raised from the farmers who use the canal to irrigate different cultivated crops in the adjacent area along the canal. Water samples, surface soil samples at 0-20 cm depth and a field crop samples were taken from five sites along Bani Ghalib canal during two successive seasons winter and summer seasons, 2017. The locations were selected using GPS and shown in Figure 1. (Arab El-Madabegh 27 9' 50.38" N, 31 $1^{\circ} 8^{\prime} 38.45^{\prime \prime}$; Gahdam $27^{\circ} 12^{\prime} 20.25^{\prime \prime} \mathrm{N}, 31^{\circ} 1^{\prime} 32.46^{\prime \prime}$; Al Hadaya $27^{\circ} 12^{\prime} 20.25^{\prime \prime} \mathrm{N}, 31^{\circ} 1^{\prime} 32.46^{\prime \prime}$; Elwan $27^{\circ} 12^{\prime} 3.89^{\prime \prime} \mathrm{N}, 31^{\circ} 3^{\prime}$ $3.84^{\prime \prime}$ and Mangabad $27^{\circ} 11^{\prime} 20.80^{\prime \prime} \mathrm{N}, 31^{\circ} 4^{\prime} 58.10^{\prime \prime}$ ) . 


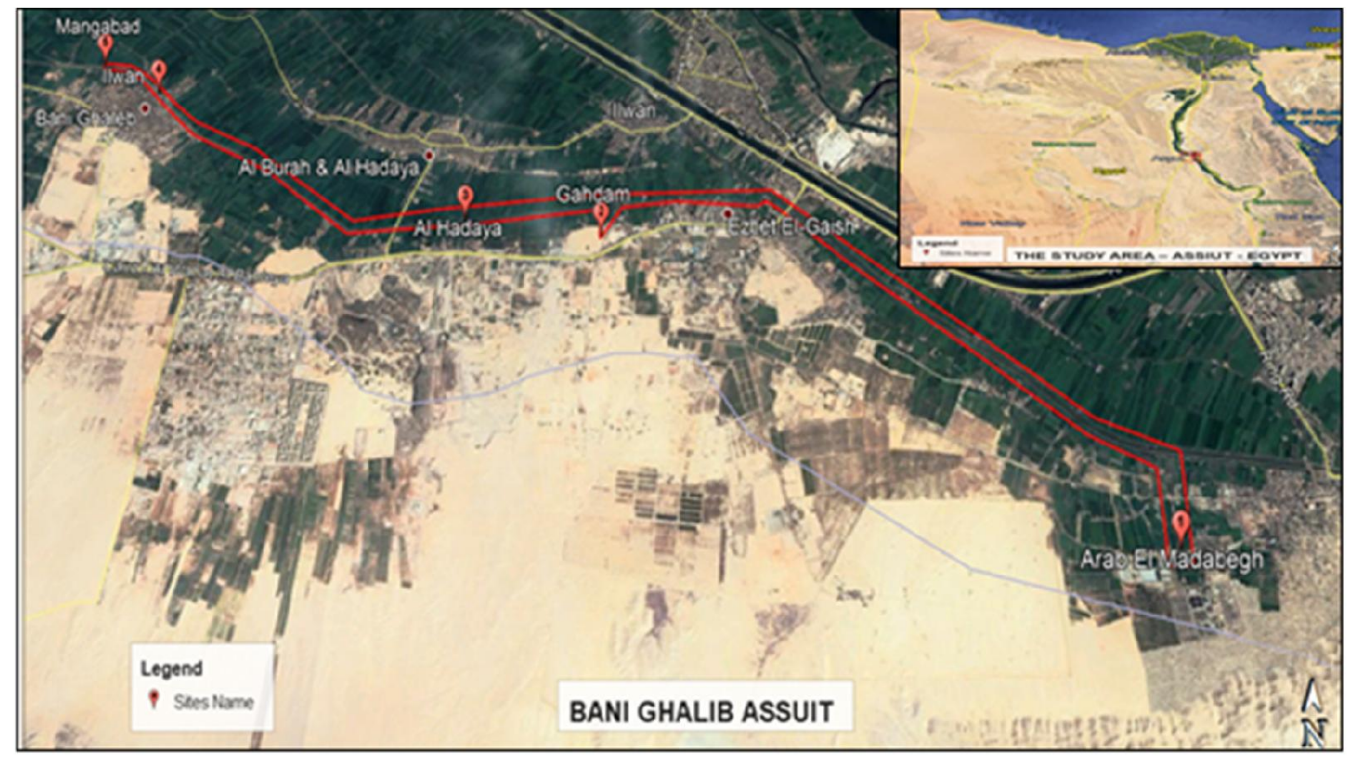

Fig.1: Map of the study area and sampling sites

\section{Water and soil samples:}

Water samples were collected from each site in pre-cleaned high- density polyethylene bottles, $1 \mathrm{ml}$ of concentrated $\mathrm{HNO}_{3} 100^{-1} \mathrm{ml}$ water sample for determination of $\mathrm{P}, \mathrm{K}$, micro nutrients and heavy metals and another bottles for chemical analyses $(\mathrm{pH}, \mathrm{EC}$, cations and anions) and soluble nitrogen according to the method described by Environment Protection Authority, (EPA, 2007) and Rocky Mountain Research Station (RMRS, 2012). Sterilized bottles were used to collect water samples for biological test. Samples (Water and soil) were brought into the lab in ice tank and stored at $4^{\circ} \mathrm{C}$ until analysis. As for soil samples, part of the samples were kept for determination of pathogenic microorganism and the rest air dried, sieved through a $<0.2 \mathrm{~mm}$ sieve and stored in the labeled polythene sampling bags for determination of the elements.

\section{Plant samples:}

A diversity of cereal crops and vegetables grown in the study area (in 3 replicates); Alfa Alfa, Cabbage, Wheat (in shoot) and Garlic, Onion (in fruits) and (Elephant forage, Arugula in winter season and Maize (in shoot), Okra and Eggplant (in fruits) in summer season. The plant samples were collected from different villages and stored in polythene sampling bags and brought to the lab in ice tank and stored at $4^{\circ} \mathrm{C}$ until for determination of pathogenic microorganism. The rest of plant samples were washed with tap water then with distilled water, air dried in a dust free room then placed in drying oven for 72 hours at $70{ }^{\circ} \mathrm{C}$ after the dryness of the sample, it was completely grinded by using the stainless mill and passed through a $0.5 \mathrm{~mm}$ sieve and stored in polyethylene bags for analysis.

\section{Analytical methods:}

Electrical conductivity (EC) in water was determined by EC meter (model WTW Series Cond 720); $\mathrm{pH}$ values in water, was determined by using $\mathrm{pH}$ meter (model WTW Series $\mathrm{pH} 720$ ); cations and anions were determined in water according to ICARDA (2013). Sodium Adsorption Ratio (SAR) was calculated in water according to Motsara and Roy (2008). The following determinations were made based on the methods described by AOAC (1995); Available nitrogen in soil was extracted using $2 \mathrm{~N} \mathrm{KCl}$. Total nitrogen was determined by mixed acids. Soluble ( $\mathrm{P}, \mathrm{Fe}, \mathrm{Mn}, \mathrm{Cu}, \mathrm{B}, \mathrm{Cd}, \mathrm{Co}, \mathrm{Cr}$, $\mathrm{Ni}$ and $\mathrm{Pb}$ ) in water were acidified with $\mathrm{HNO}_{3}(1 \mathrm{ml}$ acid for $100 \mathrm{ml}$ water) Eaton et al. (2005). Available ( $\mathrm{P}, \mathrm{Fe}, \mathrm{Mn}, \mathrm{Cu}, \mathrm{B}, \mathrm{Cd}, \mathrm{Co}, \mathrm{Cr}, \mathrm{Ni}$ and $\mathrm{Pb})$ in soil were extracted according to the method of Soltanpour (1991). Total elements ( $\mathrm{P}, \mathrm{Fe}, \mathrm{Mn}, \mathrm{Cu}, \mathrm{B}, \mathrm{Cd}, \mathrm{Co}, \mathrm{Cr}, \mathrm{Ni}$ and $\mathrm{Pb}$ ) were digested by using aqua regia ( $\mathrm{HCl}$ and $\mathrm{HNO}_{3}$ ) according to Cottenie et al. (1982) and ICARDA (2013).

For plant analysis, it was digested using a mixture of sulphuric and percloric acids $\left(\mathrm{HClO}_{4}+\mathrm{H}_{2} \mathrm{SO}_{4}\right)$ acids according to the procedure of Benton (2001). Elements in water, soil and plant 
were determined for $(\mathrm{P}, \mathrm{Fe}, \mathrm{Mn}, \mathrm{Cu}, \mathrm{B}, \mathrm{Cd}, \mathrm{Co}, \mathrm{Cr}, \mathrm{Ni}$ and $\mathrm{Pb})$ using inductively coupled plasma (ICP) Spectrometry (model Ultima 2 JY Plasma) according Environmental Protection Agency (EPA, 1991).

Biochemical parameters including Total Suspended Solid (TSS), Chemical Oxygen Demand (COD), Biological Oxygen Demand (BOD), in water according to the methods described in APHA (1992). Microbiological analyses by the quantification of Total Coliform, Fecal Coliform were detected by multiple-tube fermentation technique (MPN), Salmonella and Shigella population were counted on XLD agar medium using the serial dilution poured plate method according to the methods described in APHA (1992).

\section{Data analyses, assessments factors and equations used:}

\subsection{Contamination Factors $(\mathbf{C F})$ :}

The contamination factor (CF) is used to determine contamination status in the studied surface soil samples (Liu et al. 2005) and calculated according to Equation No. (1).

$$
C F=\frac{\text { Measured concentration }}{\text { Background concentration }} \text { (1) }
$$

The background concentrations of different elements under study in $\mathrm{mg} \mathrm{kg}^{-1}$ in the Earth's crust were 47200 for $\mathrm{Fe} ; 850$ for $\mathrm{Mn}$; 95 for $\mathrm{Zn}$; 45 for $\mathrm{Cu}$; 100 for B; 0.3 for $\mathrm{Cd}$; 19 for $\mathrm{Co}$; 90 for $\mathrm{Cr}$; 68 for Ni and 23.9 for $\mathrm{Pb}_{\mathrm{gkg}}{ }^{-1}$ according to Turekian and Wedepohl (1961) and Bradford et al. (1996). The significance of contamination factor and the level of contamination values are described according to Häkanson (1980).

\subsection{Contamination Degree $(\mathrm{Cd})$ :}

The $\mathrm{Cd}$ is the sum of the contamination factors of all the elements examined according to Häkanson (1980).

$$
\mathrm{Cd}=\sum_{I=1}^{i=n} C F \quad \text { Equation No.(2). }
$$

\subsection{Modified degree of contamination ( $\mathrm{mCd})$ :} follows:

The (mCd) was defined as the sum of all contamination factors Abrahim (2005) and calculated as

$$
\mathrm{mCd}=\sum_{i=1}^{i=n} C F / n \quad \text { Equation No.(3) }
$$

Where: $(\mathrm{n})=$ number of analyzed elements; $(\mathrm{i}=1)=$ the elements and $(\mathrm{CF})=$ contamination factor. The classification and description of the modified degree of contamination $(\mathrm{mCd})$ in soil show the following gradations are proposed by Abrahim and Parker (2008).

\subsection{The pollution load index (PLI):}

The PLI proposed by Tomlinson et al. (1980) is calculated using the following equation.

$$
\mathrm{PLI}=(\mathrm{CF} 1 \times \mathrm{CF} 2 \times \mathrm{CF} 3 \times \ldots . . \times \mathrm{CFn})^{1 / n} \quad \text { Equation No. (4). }
$$

\subsection{Enrichment Factor (EF).}

The value of the enrichment factor was calculated as expressed by Buat-Menard and Chesselet (1979) following equation.

$$
E F=\left(C_{m} / C_{\text {Background }}\right) /\left(F e_{m} / F e_{\text {Background }}\right) \quad \text { Equation No. (5) }
$$

Where, $\mathrm{C}_{\mathrm{m}}$ is the concentration of the heavy metals in the study site, $\mathrm{C}_{\text {background }}$ is the concentration of the reference heavy metals in the study site 
$\mathrm{Fe}_{\mathrm{m}}$ is the concentration of the examined heavy metal in the control sample, $\mathrm{Fe}$ background is the concentration of the reference heavy metal in the control sample. Iron was used as a reference heavy metal and the value obtained from the control sample was used as the reference value according to (Rashed, 2008).

\subsection{Bio concentration factor $(B C F)$ :}

The BCF is calculated according to Liu et al. (2006) using the following equation

$$
\mathrm{BCF}=\mathrm{C}_{\text {plant }} / \mathrm{C}_{\text {soil }} \quad \text { Equation No. (6) }
$$

where: $-\mathrm{C}_{\text {plant }}$ is the concentration of elements in the plant and $\mathrm{C}$ soil is the concentration of the same elements in the soil on dry weight basis.

\section{Results and Discussion}

\section{Irrigation water quality of Bani Ghalib canal:}

\subsection{Salinity hazard:}

Data presented in Table (1) show the average of the chemical composition of Bani Ghalib canal water in different sites during the monitoring period from winter to summer seasons. The total soluble salts (TDS) of water ranged from 522 to $613 \mathrm{mgL}^{-1}$. Whereas the SAR values ranged from 4.22 to 4.53 (comparing the control sample (Nile water) which has $230 \mathrm{mgL}^{-1}$ for (TDS) and 0.49 for (SAR). The highest and the lowest values for TDS were (563 and 480) and (698 and 512) in winter and summer seasons, respectively. From the obtained data, it could be noticed that the water is considered high salinity and low sodium hazard $\left(\mathrm{C}_{3} \mathrm{~S}_{1}\right)$ in the degree of restriction for irrigation purposes with comparing to Nile water which considered medium salinity and low sodium hazard $\left(\mathrm{C}_{2} \mathrm{~S}_{1}\right)$ according to (Richards 1954 and FAO 1985). The mean values of EC $\left(\mathrm{dS} \mathrm{m}^{-1}\right)$ ranged from 0.82 to $0.96 \mathrm{dS} \mathrm{m}^{-1}$ compared with EC in Nile water which was $0.36\left(\mathrm{dS} \mathrm{m}^{-1}\right)$ considered the water was restriction for use irrigation purposes according to Doneen (1954).

\section{2.pH values:}

The obtained data showed that the $\mathrm{pH}$ of water at all sites along Babi Ghalib canal was more than the guidelines; it ranges between 7.44 to 7.53 and 7.12 to 7.50 at winter and summer, respectively. The lowest $\mathrm{pH}$ values may be due to dissolved organic matter in Bani Ghalib irrigation water.

It can be stated that according to FAO (1985) guidelines for interpretations of water quality for irrigation, small serious problems are expected from using Bani Ghalib canal water with this salinity level for irrigation and it can be adapted by good soil management (tillage, organic and green manures) with selection of crops or crops tolerant varieties.

\section{3. $\mathrm{NH}_{4}{ }^{+}$and $\mathrm{P}$ content:}

The data in Table (2) showed that sites of (Arab El Madabegh, Gahdam, Al Hadaya, Elwan and Mangabad) have moderately to high concentration of $\mathrm{NH}_{4}{ }^{+}$in some sites especially in summer season compared with the critical limits $\left(<5.0 \mathrm{mgL}^{-1}\right)$.

It is classified as "slight to moderate to high" in the degree of the restriction in use for irrigation because of discharged municipal wastewater to the Bani Ghalib canal water. The lowest values for $\mathrm{NH}_{4}{ }^{+}$and $\mathrm{P}$ ranged from 13.00 to $20.00 \mathrm{mg} \mathrm{l}^{-1}$ and 2.97 to $3.55 \mathrm{mgL}^{-1}$ and the highest values ranged from 30.40 to 43.60 and 22.99 to $35.50 \mathrm{mgL}^{-1}$ with average 23.56 and $34.10 \mathrm{mgL}^{-1}$ for $\mathrm{NH}_{4}{ }^{+}$and 7.70 and $11.16 \mathrm{mgL}^{-1}$ for Pat winter and summer seasons respectively. It can be concluded that in most sites, the concentration of $\mathrm{NH}_{4}^{-}$and $\mathrm{P}$ exceed the critical limits for irrigation in summer season. According the FAO (1985), it is classified as "slight to moderate to high" for $\mathrm{NH}_{4}{ }^{+}$and "Slight to moderate " for P respectively in the degree of the restriction in use for irrigation.

\subsection{Some macro, micro and heavy metals content:}

Macro, micro nutrients and heavy metals concentration in Bani Ghalib canal water are presented in Table (2). The average concentration of some elements is below the critical limits for irrigation according to the Egyptian guidelines 
Table 1: Soluble cations and anions of irrigation water of Bani Ghalib canal at different Sites.

\begin{tabular}{|c|c|c|c|c|c|c|c|c|c|c|c|c|c|c|}
\hline \multirow{3}{*}{ 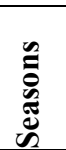 } & \multirow{3}{*}{$\begin{array}{c}\text { Sites } \\
\text { Nile water }\end{array}$} & \multirow{2}{*}{$\mathbf{p H}$} & \multirow{2}{*}{$\begin{array}{c}\text { TDS } \\
\text { mgL }^{-1}\end{array}$} & \multirow{2}{*}{$\begin{array}{c}\mathbf{E C}_{\mathbf{w}} \\
\mathbf{d S} \mathbf{m}^{-1}\end{array}$} & \multicolumn{4}{|c|}{ Cations (meq $\left.\mathbf{L}^{-1}\right)$} & \multicolumn{4}{|c|}{ Anions (meq $\left.\mathrm{L}^{-1}\right)$} & \multirow{2}{*}{ SAR } & \multirow{2}{*}{$\begin{array}{l}\text { Water } \\
\text { Class* }\end{array}$} \\
\hline & & & & & $\mathbf{C a}^{++}$ & $\mathbf{M g}^{++}$ & $\mathrm{Na}^{+}$ & $\mathbf{K}^{+}$ & $\mathrm{CO}_{3}^{-}$ & $\mathrm{HCO}_{3}^{-}$ & $\mathrm{Cl}^{-}$ & $\mathrm{SO}_{4}{ }^{=}$ & & \\
\hline & & 7.65 & 230 & 0.36 & 1.74 & 1.22 & 0.6 & 0.08 & $\mathrm{Nd}$ & 2.01 & 0.86 & 0.77 & 0.49 & $\mathrm{C}_{2} \mathrm{~S}_{1}$ \\
\hline \multirow{5}{*}{ 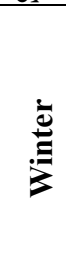 } & $\begin{array}{l}\text { Arab El } \\
\text { Madabegh }\end{array}$ & 7.53 & 563 & 0.88 & 1.00 & 2.00 & 4.45 & 0.35 & $\mathrm{Nd}$ & 2.10 & 5.20 & 0.50 & 3.63 & $\mathrm{C}_{3} \mathrm{~S}_{1}$ \\
\hline & Gahdam & 7.49 & 531 & 0.83 & 1.00 & 1.00 & 5.69 & 0.31 & $\mathrm{Nd}$ & 1.90 & 5.10 & 1.00 & 5.69 & $\mathrm{C}_{3} \mathrm{~S}_{1}$ \\
\hline & Al Hadaya & 7.48 & 480 & 0.75 & 1.20 & 1.00 & 4.96 & 0.24 & $\mathrm{Nd}$ & 2.00 & 3.80 & 1.60 & 4.73 & $\mathrm{C}_{3} \mathrm{~S}_{1}$ \\
\hline & Elwan & 7.44 & 506 & 0.79 & 1.50 & 1.50 & 4.12 & 0.28 & $\mathrm{Nd}$ & 2.90 & 4.00 & 0.50 & 3.36 & $\mathrm{C}_{3} \mathrm{~S}_{1}$ \\
\hline & Mangabad & 7.52 & 531 & 0.83 & 1.00 & 2.00 & 4.52 & 0.28 & $\mathrm{Nd}$ & 2.90 & 4.20 & 0.70 & 3.69 & $\mathrm{C}_{3} \mathrm{~S}_{1}$ \\
\hline \multicolumn{2}{|c|}{ Minimum } & 7.44 & 480 & 0.75 & 1.00 & 1.00 & 4.12 & 0.24 & $\mathrm{Nd}$ & 1.90 & 3.80 & 0.50 & 3.36 & \\
\hline \multicolumn{2}{|c|}{ Maximum } & 7.53 & 563 & 0.88 & 1.50 & 2.00 & 5.69 & 0.35 & $\mathrm{Nd}$ & 2.90 & 5.20 & 1.60 & 5.69 & \\
\hline \multicolumn{2}{|c|}{ Average } & 7.49 & 522 & 0.82 & 1.14 & 1.50 & 4.75 & 0.29 & $\mathrm{Nd}$ & 2.36 & 4.46 & 0.86 & 4.22 & \\
\hline \multirow{4}{*}{$\stackrel{\grave{\Xi}}{\grave{\Xi}}$} & $\begin{array}{l}\text { Arab EI } \\
\text { Madabegh }\end{array}$ & 7.16 & 698 & 1.09 & 1.24 & 2.48 & 5.51 & 0.43 & $\mathrm{Nd}$ & 2.60 & 6.44 & 0.62 & 4.04 & $\mathrm{C}_{3} \mathrm{~S}_{1}$ \\
\hline & Gahdam & 7.38 & 512 & 0.8 & 0.96 & 0.96 & 5.48 & 0.30 & $\mathrm{Nd}$ & 1.83 & 4.92 & 0.96 & 5.59 & $\mathrm{C}_{3} \mathrm{~S}_{1}$ \\
\hline & Al Hadaya & 7.50 & 595 & 0.93 & 1.49 & 1.24 & 6.15 & 0.30 & $\mathrm{Nd}$ & 2.48 & 4.71 & 1.98 & 5.27 & $\mathrm{C}_{3} \mathrm{~S}_{1}$ \\
\hline & Elwan & 7.40 & 691 & 1.08 & 2.05 & 2.05 & 5.63 & 0.38 & $\mathrm{Nd}$ & 3.96 & 5.47 & 0.68 & 3.93 & $\mathrm{C}_{3} \mathrm{~S}_{1}$ \\
\hline \multicolumn{2}{|c|}{ Minimum } & 7.12 & 512 & 0.80 & 0.96 & 0.96 & 4.85 & 0.30 & $\mathrm{Nd}$ & 1.83 & 4.50 & 0.62 & 3.82 & \\
\hline \multicolumn{2}{|c|}{ Maximum } & 7.50 & 698 & 1.09 & 2.05 & 2.48 & 6.15 & 0.43 & $\mathrm{Nd}$ & 3.96 & 6.44 & 1.98 & 5.59 & \\
\hline \multicolumn{2}{|c|}{ Average } & 7.31 & 613 & 0.96 & 1.36 & 1.78 & 5.53 & 0.34 & $\mathrm{Nd}$ & 2.80 & 5.21 & 1.00 & 4.53 & \\
\hline \multicolumn{2}{|c|}{ Guidelines } & $6.5-8.4^{\mathrm{a}}$ & 512 & $0.7-3^{\mathrm{a}}$ & -- & -- & $3-9^{a}$ & -- & -- & $1.5-8.5^{\mathrm{a}}$ & $4-10^{a}$ & -- & $10-18^{b}$ & \\
\hline
\end{tabular}

*Classification of water class according to Richards (1954). a- FAO (1985) and b- Motsara and Roy (2008).

$\mathrm{C} 2 \mathrm{~S} 1=$ Medium salinity, low sodium hazard C3S1=High salinity, low sodium hazard

$\mathrm{C} 4 \mathrm{~S} 1=$ Very high salinity, low sodium hazardECiw $=$ Electrical conductivity of irrigation water. 
Table 2: Some macro, micro and heavy metals of irrigation water of Bani Ghalib canal at different sites.

\begin{tabular}{|c|c|c|c|c|c|c|c|c|c|c|c|c|c|}
\hline \multirow{3}{*}{$\begin{array}{l}\mathscr{E} \\
\stackrel{\tilde{D}}{\tilde{E}} \\
\tilde{\mathscr{E}}\end{array}$} & \multirow{2}{*}{ Sites } & \multicolumn{12}{|c|}{ Concentration $\left(\mathrm{mgL}^{-1}\right)$} \\
\hline & & $\mathrm{NH}_{4}{ }^{+}$ & $\mathbf{P}$ & $\mathbf{F e}$ & Mn & Zn & $\mathrm{Cu}$ & B & Cd & Co & $\mathrm{Cr}$ & $\mathbf{N i}$ & $\mathbf{P b}$ \\
\hline & Nile water & 4.12 & 0.01 & 0.02 & 0.02 & 0.01 & 0.001 & 0.024 & $\mathrm{Nd}$ & $\mathrm{Nd}$ & $\mathrm{Nd}$ & $\mathrm{Nd}$ & 0.005 \\
\hline \multirow{5}{*}{ 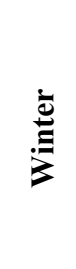 } & $\begin{array}{l}\text { Arab El } \\
\text { Madabegh }\end{array}$ & 30.4 & 4.90 & 0.05 & 0.10 & 0.01 & 0.02 & 0.36 & 0.07 & $\mathrm{Nd}$ & $\mathrm{Nd}$ & 0.03 & 0.03 \\
\hline & Gahdam & 13.0 & 2.97 & 0.11 & 0.08 & 0.02 & 0.02 & 0.21 & 0.10 & $\mathrm{Nd}$ & 0.01 & $\mathrm{Nd}$ & 0.03 \\
\hline & Al Hadaya & 22.9 & 22.99 & 3.35 & 0.11 & 0.05 & 0.02 & 0.38 & 0.11 & $\mathrm{Nd}$ & $\mathrm{Nd}$ & 0.02 & 0.02 \\
\hline & Elwan & 26.0 & 4.29 & 0.13 & 0.14 & 0.05 & 0.03 & 0.28 & 0.07 & $\mathrm{Nd}$ & $\mathrm{Nd}$ & $\mathrm{Nd}$ & 0.08 \\
\hline & Mangabad & 25.5 & 3.34 & 0.04 & 0.11 & 0.03 & 0.04 & 0.24 & 0.08 & $\mathrm{Nd}$ & $\mathrm{Nd}$ & 0.02 & 0.01 \\
\hline \multicolumn{2}{|c|}{ Minimum } & 13.00 & 2.97 & 0.04 & 0.08 & 0.01 & 0.02 & 0.21 & 0.07 & $\mathrm{Nd}$ & $\mathrm{Nd}$ & $\mathrm{Nd}$ & 0.01 \\
\hline \multicolumn{2}{|c|}{ Maximum } & 30.40 & 22.99 & 3.35 & 0.14 & 0.05 & 0.04 & 0.38 & 0.11 & $\mathrm{Nd}$ & 0.01 & 0.03 & 0.08 \\
\hline \multicolumn{2}{|c|}{ Average } & 23.56 & 7.70 & 0.73 & 0.11 & 0.03 & 0.03 & $* 0.30$ & 0.08 & $\mathrm{Nd}$ & $\mathrm{Nd}$ & 0.01 & 0.04 \\
\hline \multirow{5}{*}{$\begin{array}{l}\dot{\bar{\Xi}} \\
\text { Ĕ } \\
\bar{E}\end{array}$} & $\begin{array}{l}\text { Arab EI } \\
\text { Madabegh }\end{array}$ & 43.6 & 7.42 & 0.17 & 0.13 & 0.02 & 0.02 & 0.57 & 0.11 & $\mathrm{Nd}$ & $\mathrm{Nd}$ & 0.03 & 0.04 \\
\hline & Gahdam & 20.0 & 3.55 & 0.27 & 0.10 & 0.22 & 0.03 & 0.24 & 0.59 & $\mathrm{Nd}$ & 0.01 & $\mathrm{Nd}$ & 0.04 \\
\hline & Al Hadaya & 35.5 & 35.50 & 2.94 & 0.13 & 0.08 & 0.03 & 0.40 & 0.11 & $\mathrm{Nd}$ & $\mathrm{Nd}$ & 0.03 & 0.03 \\
\hline & Elwan & 39.5 & 5.53 & 0.17 & 0.16 & 0.20 & 0.03 & 0.42 & 0.09 & $\mathrm{Nd}$ & $\mathrm{Nd}$ & $\mathrm{Nd}$ & 0.23 \\
\hline & Mangabad & 31.9 & 3.80 & 0.16 & 0.23 & 0.05 & 0.08 & 0.42 & 0.09 & $\mathrm{Nd}$ & 0.01 & 0.11 & 0.02 \\
\hline \multicolumn{2}{|c|}{ Minimum } & 20.00 & 3.55 & 0.16 & 0.10 & 0.02 & 0.02 & 0.24 & 0.09 & $\mathrm{Nd}$ & $\mathrm{Nd}$ & $\mathrm{Nd}$ & 0.02 \\
\hline \multicolumn{2}{|c|}{ Maximum } & 43.60 & 35.50 & 2.94 & 0.23 & 0.22 & 0.08 & 0.57 & 0.59 & $\mathrm{Nd}$ & 0.01 & 0.11 & 0.23 \\
\hline \multicolumn{2}{|c|}{ Average } & 34.10 & 11.16 & 0.74 & 0.15 & 0.11 & 0.04 & 0.41 & 0.20 & $\mathrm{Nd}$ & $\mathrm{Nd}$ & 0.04 & 0.07 \\
\hline \multicolumn{2}{|c|}{ Guidelines* } & $5-30$ & $3-5$ & 5 & 0.2 & 2 & 0.02 & 0.7 & 0.01 & -- & 0.1 & 0.2 & 5 \\
\hline
\end{tabular}


The data in Table (2) showed that in all sites (Arab El Madabegh, Gahdam, Al Hadaya, Elwan and Mangabad) there are a low concentration of $\mathrm{Fe}, \mathrm{Mn}, \mathrm{Zn}, \mathrm{Cu}, \mathrm{B}, \mathrm{Cd}, \mathrm{Co}, \mathrm{Cr}$. $\mathrm{Ni}$ and $\mathrm{Pb}$ which not exceed the critical limits for winter and summer seasons, it is classified as "good to slight" in the degree of the restriction in use for irrigation purposes. But, there are some values for some elements such as $\mathrm{Fe}, \mathrm{Mn}, \mathrm{Cu}$ and $\mathrm{Pb}$ which exceed the critical limits in some sites because of discharge of wastewater to the canal water. It can be concluded that continuously discharge municipal waste water to canal water increase the pollutants of some heavy metals.

Macro, micro nutrients and heavy metals concentration in Bani Ghalib canal water are presented in Table (2). The average concentration of some elements is below the critical limits for irrigation according to (FAO 1985), guidelines. This may be due to the behavior of the heavy elements, which are deposited in the bottom of the canal concentrations did not exceed the critical limits.

\section{Soils irrigated from Bani Ghalib canal:}

\subsection{Available $N$ and $P$ contents in soil:}

Data in Table (3) showed that, the available elements of the studied soil samples in all sites (Arab El Madabegh, Gahdam, Al Hadaya, Elwan and Mangabad) have high concentration of $\mathrm{N}$ and $\mathrm{P}$ in most month exceed the critical limits $\left(<30.0\right.$ and $<8.0 \mathrm{mg} \mathrm{kg}^{-1}$ soil according to (Soltanpour 1985). This may be due to discharged municipal wastewater to the Bani Ghalib canal water.

The mean values of $\mathrm{N}$ and $\mathrm{P}$ ranged from 140.18 to $154.07 \mathrm{mg} \mathrm{kg}^{-1}$ and 41.83 to $57.00 \mathrm{mg} \mathrm{kg}^{-1}$ soil in winter and summer seasons respectively, As well as the lowest and highest values for $\mathrm{N}$ were 41.48 to $48.00 \mathrm{mg} \mathrm{kg}^{-1}$ and 344.40 to $367.40 \mathrm{~kg}^{-1}$ soil and for $\mathrm{P}$ were 33.00 to $35.60 \mathrm{mg} \mathrm{kg}^{-1}$ and 64.10 to $79.50 \mathrm{mg} \mathrm{kg}^{-1}$ soil, respectively. It can be concluded that in most sites in two winter and summer seasons, the concentration of available $\mathrm{N}$ and $\mathrm{P}$ in soil exceeds the critical limits.

\subsection{Available micro-nutrients and heavy metals contents in soil at different sites:}

The obtained data (Table 3) showed that in all sites (Arab El Madabegh, Gahdam, Al Hadaya, Elwan and Mangabad) there were a high content of available $\mathrm{Fe}, \mathrm{Mn}, \mathrm{Zn}$ and $\mathrm{Cu}$ which exceed the critical limits for monitoring at both of two seasons (Soltanpour 1985), also $\mathrm{Pb}$ was high adverse effects more likely, Michael et al. (2007). Available B was low content in all sites exception Gahdam site was high content, while $\mathrm{Cd}, \mathrm{Co}, \mathrm{Ni}$ and $\mathrm{Cr}$ were low content at both winter and summer seasons respectively. As well as $\mathrm{Ni}$ was moderate effects. It was clear that the content of the element which exceed the critical limits in some sites because of discharge of wastewater to the canal water. It could be concluded that continuously discharge municipal waste water to canal water increase the content of some heavy metals. Increased available content in soils of $\mathrm{Fe}, \mathrm{Mn}, \mathrm{Zn}, \mathrm{Cu}$ and $\mathrm{Pb}$ may be due to the parent material of the soil or the increase in fertilization and /or the presence of industrial waste.

\section{Micro-element and some heavy metals content in different plants irrigated from Bani Ghalib canal:}

Data showed in Table (4) showed that the different values of $\mathrm{Fe}, \mathrm{Mn}, \mathrm{Zn}, \mathrm{Cu}, \mathrm{B}, \mathrm{Cd}, \mathrm{Co}, \mathrm{Cr}, \mathrm{Ni}$ and $\mathrm{Pb}$ in plants grown was affected by irrigation water at different sites during winter and summer seasons.

Regarding to Fe content in different plants grown in this villages (Arab El Madabegh, Gahdam, Al Hadaya, Elwan and Mangabad) was very-very high with all different plants; while content of Mn was moderately concentration. $\mathrm{Zn}$ and $\mathrm{Cu}$ content were high in Wheat, Elephant forage, Okra and Arugula. Also $\mathrm{Cu}$ in Alfa Alfa; as well as B content in different plants was low exception Garlic and Maize in Elwan site were high concentration. Concerning Ni content in different plants were very high in Alfa Alfa, Cabbage, Garlic, Onion, Wheat, Elephant forage, Okra and Arugula; was medium in Eggplant and was low on Maize plant. Regard to heavy metals $\mathrm{Cd}$ and $\mathrm{Pb}$ were safe and below the permissible level but $\mathrm{Co}$ and $\mathrm{Cr}$ were toxic and higher than the permissible limits according to Bennett (1993), Adriano (1986) and Misra and Mani (1991) and Indian Standard (Awashthi 2000). These results correspond with Sherif and Atwany (2019), who found that, Fe content in different plants grown behind industrial zone was very-very high with all different plants; while content of $\mathrm{Mn}$ was low. Zn content was high in Arugula, Mallow and Wheat and low in Faba bean, Okra fruits, Melokhia, Spinach and Cabbage; as well as $\mathrm{Cu}$ content in different plants was high in Arugula, Faba 
Table 3: Available macro, micro and heavy metals of soils irrigated from Bani Ghalib canal at different sites.

\begin{tabular}{|c|c|c|c|c|c|c|c|c|c|c|c|c|c|}
\hline \multirow{2}{*}{$\begin{array}{l}\mathscr{a} \\
\tilde{\Xi} \\
\tilde{E} \\
\tilde{E}\end{array}$} & \multirow[b]{2}{*}{ Sites } & \multicolumn{12}{|c|}{ Concentration $\left(\mathrm{mg} \mathrm{kg}^{-1}\right)$} \\
\hline & & $\mathbf{N}$ & $\mathbf{P}$ & $\mathbf{F e}$ & Mn & $\mathbf{Z n}$ & $\mathbf{C u}$ & B & Cd & Co & $\mathrm{Cr}$ & $\mathbf{N i}$ & $\mathbf{P b}$ \\
\hline \multirow{5}{*}{ 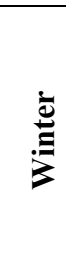 } & \multirow{2}{*}{$\begin{array}{l}\text { Arab EI } \\
\text { Madabegh } \\
\text { Gahdam }\end{array}$} & 42.0 & 64.1 & 80.60 & 11.26 & 5.98 & 2.44 & 0.22 & 0.03 & 0.15 & 0.44 & 0.74 & 4.97 \\
\hline & & 41.5 & 33.0 & 30.21 & 11.72 & 2.22 & 3.68 & 1.24 & 0.03 & 0.10 & 1.01 & 0.61 & 1.95 \\
\hline & Al Hadaya & 86.0 & 34.0 & 20.34 & 13.32 & 2.02 & 5.10 & 0.34 & 0.03 & 0.14 & 1.01 & 0.48 & 1.10 \\
\hline & Elwan & 187.0 & 40.9 & 40.62 & 8.86 & 5.44 & 6.34 & 0.36 & 0.03 & 0.05 & 0.60 & 0.92 & 1.66 \\
\hline & Mangabad & 344.4 & 37.2 & 85.46 & 14.42 & 6.98 & 6.22 & 0.36 & 0.05 & 0.13 & 1.40 & 1.00 & 2.76 \\
\hline \multicolumn{2}{|c|}{ Minimum } & 41.48 & 33.00 & 20.34 & 8.86 & 2.02 & 2.44 & 0.22 & 0.03 & 0.05 & 0.44 & 0.48 & 1.10 \\
\hline \multicolumn{2}{|c|}{ Maximum } & 344.40 & 64.10 & 85.46 & 14.42 & 6.98 & 6.34 & 1.24 & 0.05 & 0.15 & 1.40 & 1.00 & 4.97 \\
\hline \multicolumn{2}{|c|}{ Average } & 140.18 & 41.83 & 51.45 & 11.92 & 4.53 & 4.76 & 0.50 & 0.03 & 0.11 & 0.89 & 0.75 & 2.49 \\
\hline \multirow{4}{*}{ 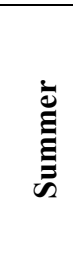 } & \multirow{2}{*}{$\begin{array}{l}\text { Arab EI } \\
\text { Madabegh } \\
\text { Gahdam }\end{array}$} & 48.00 & 79.50 & 91.70 & 7.10 & 6.02 & 6.04 & 0.28 & 0.03 & 0.14 & 0.99 & 0.98 & 4.90 \\
\hline & & 56.25 & 35.60 & 40.22 & 17.73 & 2.60 & 5.17 & 1.59 & 0.05 & 0.14 & 1.09 & 0.84 & 2.35 \\
\hline & Al Hadaya & 106.70 & 43.50 & 23.50 & 16.25 & 3.26 & 5.24 & 0.42 & 0.04 & 0.19 & 1.18 & 0.66 & 1.16 \\
\hline & Mangabad & 367.40 & 72.90 & 120.60 & 39.90 & 11.31 & 7.82 & 0.69 & 0.06 & 0.14 & 1.68 & 1.85 & 3.48 \\
\hline \multicolumn{2}{|c|}{ Minimum } & 48.00 & 35.60 & 23.50 & 7.10 & 2.60 & 5.17 & 0.28 & 0.03 & 0.07 & 0.90 & 0.66 & 1.16 \\
\hline \multicolumn{2}{|c|}{ Maximum } & 367.40 & 79.50 & 120.60 & 39.90 & 11.31 & 7.88 & 1.59 & 0.06 & 0.19 & 1.68 & 1.85 & 4.90 \\
\hline \multicolumn{2}{|c|}{ Average } & 154.07 & 57.00 & 67.24 & 18.27 & 6.00 & 6.43 & 0.69 & 0.05 & 0.14 & 1.17 & 1.06 & 2.83 \\
\hline \multirow{3}{*}{$\begin{array}{l}\text { Critcal } \\
\text { Limit }^{\text {b }}\end{array}$} & Low & $0-10^{\mathrm{a}}$ & $0-3^{a}$ & $0-3^{\mathrm{a}}$ & $0-0.5^{\mathrm{a}}$ & $0-0.9^{\mathrm{a}}$ & $0-0.2^{\mathrm{a}}$ & -- & $<0.1^{\mathrm{b}}$ & -- & -- & $<0.1^{\mathrm{b}}$ & $<0.1^{b}$ \\
\hline & Medium & $11-20^{\mathrm{a}}$ & $4-7^{a}$ & $3.1-5^{\mathrm{a}}$ & $0.6-1.0^{a}$ & $1-1.5^{\mathrm{a}}$ & $0.3-0.5^{\mathrm{a}}$ & $5^{\mathrm{a}}$ & $0.1-0.5^{b}$ & -- & -- & $0.1-5^{b}$ & $0.1-1^{b}$ \\
\hline & High & $21-30^{\mathrm{a}}$ & $8-11^{a}$ & $>5^{\mathrm{a}}$ & $>1^{\mathrm{a}}$ & $>1.5^{\mathrm{a}}$ & $>0.5^{\mathrm{a}}$ & $>5^{\mathrm{a}}$ & $>0.5^{\mathrm{b}}$ & -- & -- & $>5^{\mathrm{b}}$ & $>1^{\mathrm{b}}$ \\
\hline
\end{tabular}

a - Soltanpour (1985) and b- Michael et al. (2007). 
Table 4: Micro-element and some heavy metals content of different plants irrigated from Bani Ghalib canal at different sites.

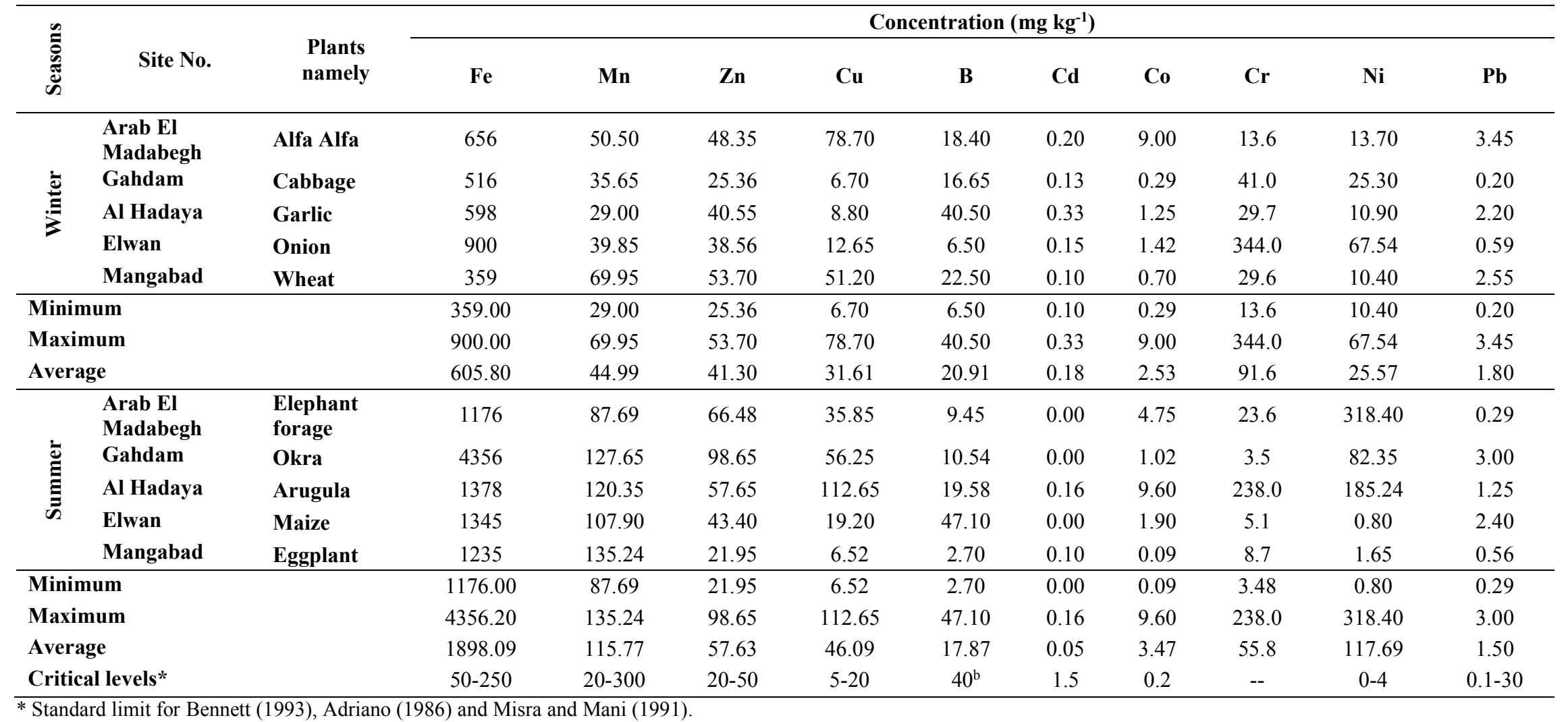


bean, Okra fruits and Melokhia, and was low in Mallow, Wheat, Spinach and Cabbage. $\mathrm{Cr}$ and $\mathrm{Pb}$ were safe and below the permissible level but $\mathrm{Ni}$ was toxic and higher than the permissible limits.

Generally, the highest content values in different plants were as follows: Okra for $\mathrm{Fe}, \mathrm{Zn}$ and $\mathrm{Pb}$; Eggplant for Mn and Maize for B; Garlic for Cd; Arugula for Co; Onion for Cr and Elephant forage for Ni. It is clear that the concentration of the element which exceeds the critical limits in some sites may be because of discharge of wastewater to Bani Ghalib canal. It can be concluded that continuously discharge municipal wastewater to Bani Ghalib canal increase the pollutants of some heavy metals in plants.

In general, there are high concentrations of elements in plants where it turns out the presence of high concentrations of copper element in plants alfalfa, wheat, Elephant forage, Okra and Arugula from Arab El Madabegh, Mangabad, Gahdam and Al Hadaya villages. There was also cobalt pollution in alfalfa and Arugula plants in the Arab El Madabegh and Al Hadaya villages. It could be concluded that accumulation of heavy metals in edible plants one of the causes of cancer in humans.

\section{Some biological parameters in water, soil and different plants irrigated from Bani Ghalib canal}

4.1. Irrigation water:

The average values of biological parameters of irrigation water are presented in Table (5). Total suspended solid (TSS), chemical and biological oxygen demand values (COD and BOD) increased in irrigation water at different sites along the Bani Ghalib canal in comparison with Nile water. These increased values exceeded the permissible limits according to the law 48 for the year 1983 . The values ranged from 556 to $2560 \mathrm{mgL}^{-1}$ with average of $970 \mathrm{mgL}^{-1}$ for TSS, from 26 to $143 \mathrm{mgL}^{-1}$ with average of $77 \mathrm{mgL}^{-1}$ for COD and from 20 to 120 with average of $56 \mathrm{mgL}^{-1}$ for BOD in comparison with Nile water $\left(280,0.0\right.$ and $0.0 \mathrm{mgL}^{-1}$ for TSS, COD and BOD, respectively. Data demonstrated that, the highest obtained values for TSS found in June month in all sites and the lowest value was in July month in both. It could be noticed that, the lowest and the highest values of TSS at winter season were 350 and $720 \mathrm{mgL}^{-1}$ while in summer were 1360 and $3620 \mathrm{mgL}^{-1}$, as well as the results recorded for COD 128 and $233 \mathrm{mgL}^{-1}$ for winter season and $213,1100 \mathrm{mgL}^{-1}$ for summer season. While BOD it recorded 120 and $185 \mathrm{mgL}^{-1}$ in winter season while in summer it was 140 and $800 \mathrm{mgL}^{-1}$.

Concerning the lowest and the highest values of total coliform at winter season it was 800 and 10500 cell $100^{-1} \mathrm{ml}$ with average 5860 cell $100^{-1} \mathrm{ml}$ while in summer it was 14800 and 38600 cell $100^{-}$ ${ }^{1} \mathrm{ml}$ with average 23700 cell $100^{-1} \mathrm{ml}$, as well as lowest and the highest values for fecal coliform at winter season it was 600 and 8500 cell $100^{-1} \mathrm{ml}$ with average 3800 cell $100^{-1} \mathrm{ml}$ while in summer it was 12500 and 94000 cell $100^{-1} \mathrm{ml}$ with average 37200 cell $100^{-1} \mathrm{ml}$. With respect to salmonella and shegilla was 180 and 410 cell $100^{-1} \mathrm{ml}$ with average 282 cell $100^{-1} \mathrm{ml}$ in winter season while in summer it was 2400 and 4800 cell $100^{-1} \mathrm{ml}$ with average 3320 cell $100^{-1} \mathrm{ml}$.

From Table (5) noticed that, the highest obtained values for TSS $\mathrm{mgL}^{-1}$ at winter season found in Mangabad village, while COD \& BOD $\mathrm{mgL}^{-1}$; total coliform, facial coliform and salmonella and shigella (cell $100 \mathrm{ml}^{-1}$ ) were found in Elwan village; as well as the highest obtained values for TSS, $\mathrm{COD}$ and BOD $\mathrm{mL}^{-1}$ at summer season found in Mangabad village. Concerning total coliform, fecal coliform and salmonella and shigella (cell $100 \mathrm{ml}^{-1}$ ) were found in Arab El Madabegh village.

It can be concluded that irrigation water at all villages polluted by all biological parameters exception COD in Arab El Madabegh village at winter according to guidelines. Also, from the abovementioned data of both total and fecal coliform, it is clear that the total count of total count bacteria exceeded the critical limits for irrigation according to Guidelines FAO (1985). This type of pollution could be attributed to the unrestricted disposal of humans and industrial wastes into the irrigation canals.

\subsection{Soil and Plants:}

Data in Table (6) reveal that the surface soil $(0-20 \mathrm{~cm})$ affected by wastewater irrigation and contaminated with total coliform, fecal coliform and salmonella $\&$ and shigella in all villages site. This could be attributed to the irrigation water which contaminated with pathogenic bacteria and exposure of the soil surface to crops.

The mean obtained data in Table (6) noticed that, the lowest and the highest values of total coliform at winter season were 123 and 148 with average $137\left(\mathrm{CFU} \mathrm{g}{ }^{-1}\right)$ while in summer were 210 
Table 5: Some biological parameters of irrigation water of Bani Ghalib canal at different sites.

\begin{tabular}{|c|c|c|c|c|c|c|c|}
\hline \multirow{2}{*}{$\begin{array}{l}\mathscr{D} \\
\tilde{E} \\
\mathscr{E}\end{array}$} & Sites & $\begin{array}{c}\text { TSS } \\
\left(\mathrm{mgL}^{-1}\right)\end{array}$ & $\begin{array}{c}\text { COD } \\
\left(\mathrm{mgL}^{-1}\right)\end{array}$ & $\begin{array}{c}\text { BOD } \\
\left(\mathrm{mgL}^{-1}\right)\end{array}$ & $\begin{array}{l}\text { Total coliform } \\
\quad\left(\mathrm{CFU} \mathrm{g} \mathrm{g}^{-1}\right)\end{array}$ & 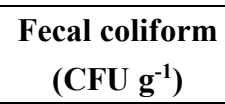 & $\begin{array}{l}\text { Salmonella \& shigella } \\
\quad\left(\text { cell } 100^{-1} \mathrm{ml}\right)\end{array}$ \\
\hline & Nile water & 280 & 0.0 & 0.0 & 163 & $\mathrm{Nd}$ & $\mathrm{Nd}$ \\
\hline \multirow{5}{*}{ 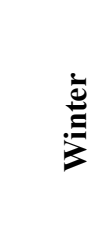 } & Arab El Madabegh & 650 & 128 & 120 & 2000 & 800 & 240 \\
\hline & Gahdam & 350 & 184 & 130 & 7500 & 5500 & 180 \\
\hline & Al Hadaya & 600 & 189 & 150 & 8500 & 3600 & 350 \\
\hline & Elwan & 460 & 233 & 185 & 10500 & 8500 & 410 \\
\hline & Mangabad & 720 & 200 & 170 & 800 & 600 & 230 \\
\hline & Minimum & 350 & 128 & 120 & 800 & 600 & 180 \\
\hline & Maximum & 720 & 233 & 185 & 10500 & 8500 & 410 \\
\hline & Average & 556 & 187 & 151 & 5860 & 3800 & 282 \\
\hline \multirow{5}{*}{$\stackrel{\grave{\Xi}}{\Xi}$} & Arab EI Madabegh & 2320 & 213 & 140 & 38600 & 94000 & 4800 \\
\hline & Gahdam & 2380 & 367 & 350 & 14800 & 12500 & 2800 \\
\hline & Al Hadaya & 3120 & 900 & 576 & 22200 & 45000 & 3700 \\
\hline & Elwan & 1360 & 889 & 470 & 21100 & 19800 & 2400 \\
\hline & Mangabad & 3620 & 1100 & 800 & 21800 & 14700 & 2900 \\
\hline \multicolumn{2}{|c|}{ Maximum } & 3620 & 1100 & 800 & 38600 & 94000 & 4800 \\
\hline \multicolumn{2}{|c|}{ Average } & 2560 & 694 & 467 & 23700 & 37200 & 3320 \\
\hline \multicolumn{2}{|c|}{ Guidelines } & $100^{(1)}$ & $150^{(1)}$ & $100^{(1)}$ & -- & $<60^{(2)}$ & $<60^{(2)}$ \\
\hline
\end{tabular}

(1) Alberta Environment (2000). ${ }^{(2)}$ FAO (1992). 
Table 6: Some biological parameters of soil and different plants irrigated with irrigation water from Bani Ghalib canal at different sites.

\begin{tabular}{|c|c|c|c|c|c|c|c|c|}
\hline \multirow{2}{*}{ 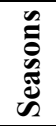 } & \multirow[b]{2}{*}{ Sites } & \multirow[b]{2}{*}{ Plant namely } & \multicolumn{3}{|c|}{ Biological parameters of soils } & \multicolumn{3}{|c|}{ Biological parameters of plants } \\
\hline & & & $\begin{array}{l}\text { Total coliform } \\
(\text { CFU g g })\end{array}$ & $\begin{array}{l}\text { Fecal coliform } \\
\left(\text { CFU g }{ }^{-1}\right)\end{array}$ & 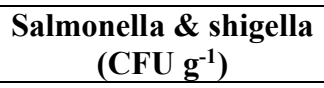 & $\begin{array}{l}\text { Total coliform } \\
(\text { CFU g g })\end{array}$ & $\begin{array}{l}\text { Fecal coliform } \\
\left.(\text { CFU g })^{-1}\right)\end{array}$ & 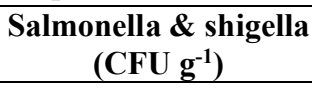 \\
\hline \multirow{5}{*}{$\stackrel{\grave{D}}{\stackrel{D}{J}}$} & $\begin{array}{l}\text { Arab El } \\
\text { Madabegh }\end{array}$ & Alfa Alfa & 148 & 121 & 135 & 200 & 120 & 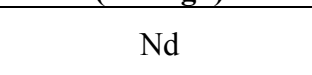 \\
\hline & Gahdam & Cabbage & 123 & 113 & 113 & $\mathrm{Nd}$ & $\mathrm{Nd}$ & $\mathrm{Nd}$ \\
\hline & Al Hadaya & Garlic & 138 & 116 & 145 & 150 & 90 & $\mathrm{Nd}$ \\
\hline & Elwan & Onion & 143 & 131 & 190 & 98 & 80 & $\mathrm{Nd}$ \\
\hline & Mangabad & Wheat & 131 & 119 & 110 & 100 & 95 & $\mathrm{Nd}$ \\
\hline \multicolumn{2}{|c|}{ Minimum } & & 123 & 113 & 110 & $\mathrm{Nd}$ & $\mathrm{Nd}$ & $\mathrm{Nd}$ \\
\hline \multicolumn{2}{|c|}{ Maximum } & & 148 & 131 & 190 & 200 & 120 & $\mathrm{Nd}$ \\
\hline \multicolumn{2}{|c|}{ Average } & & 137 & 120 & 139 & 110 & 77 & $\mathrm{Nd}$ \\
\hline \multirow{4}{*}{ 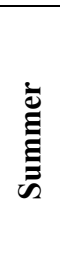 } & $\begin{array}{l}\text { Arab El } \\
\text { Madabegh }\end{array}$ & $\begin{array}{l}\text { Elephant } \\
\text { forage }\end{array}$ & 360 & 180 & 249 & 300 & 290 & $\mathrm{Nd}$ \\
\hline & Gahdam & Okra & 230 & 100 & 148 & $\mathrm{Nd}$ & $\mathrm{Nd}$ & $\mathrm{Nd}$ \\
\hline & Al Hadaya & Arugula & 210 & 100 & 154 & 10 & 86 & $\mathrm{Nd}$ \\
\hline & Elwan & Maize & 220 & 170 & 158 & $\mathrm{Nd}$ & $\mathrm{Nd}$ & $\mathrm{Nd}$ \\
\hline \multicolumn{3}{|c|}{ Minimum } & 210 & 100 & 146 & $\mathrm{Nd}$ & $\mathrm{Nd}$ & $\mathrm{Nd}$ \\
\hline \multicolumn{3}{|c|}{ Maximum } & 360 & 180 & 249 & 300 & 290 & $\mathrm{Nd}$ \\
\hline \multicolumn{3}{|c|}{ Average } & 254 & 134 & 171 & 66 & 75 & $\mathrm{Nd}$ \\
\hline \multicolumn{3}{|c|}{ Critical levels (WHO, 2006) } & -- & $<70$ & $<70$ & -- & $<30$ & $<30$ \\
\hline
\end{tabular}


and 360 with average $\left.254(\mathrm{CFU} \mathrm{g})^{-1}\right)$, as well as lowest and the highest values at winter season were 113 and 131 with average $120\left(\mathrm{CFU} \mathrm{g}^{-1}\right)$ while in summer were 100 and 180 with average 134 (CFU $\left.\mathrm{g}^{-1}\right)$ for fecal coliform while salmonella and shegilla was 110 and 190 with average $139\left(\mathrm{CFU} \mathrm{g}{ }^{-1}\right)$ in winter season while in summer were 146 and 249 with average $171\left(\mathrm{CFU} \mathrm{g}{ }^{-1}\right)$

The data presented in Table (6) indicated that all excreted pathogens can survive in soil for a sufficient length of time, while they survive on the surface of some crops for shorter time than in soil. As they are less protected from the harmful effects of sunlight and desiccation. Never less, survival times can be long enough in some cases to be potential risk to crop handlers and consumers, especially when survival times are longer than crop growing cycles, often the case with garlic. Biological pathogenic of different feed crops, field crops and vegetable crops (Total coli form and fecal coli) were detected in all plants. According to the WHO guidelines, the drainage water of Bani Ghalib is not suitable for category A of crops but it may use for irrigation of category B of crops under restriction (WHO, 2006).

With respect to Alfa Alfa, Garlic, Onion, Elephant forage, and Arugula the obtained data indicated that coliforms were detected on the surface of plants in all sites exception Cabbage and Okra in Elwan village and Eggplant in Gahdam. The obtained data are in agreement with Gerba et al. (1975) who revealed that fecal coliform can survive for several months under optimal conditions. In warm climates, survival is limited to 2-3 months. Survival of salmonella may be up to one year if the soil is cool, moist and rich in organics. Salmonella and Shigella were not detected in crop surface.

\section{Contamination Factors; Degree of Contamination, Modified Degree of Contamination and Pollution Load Index:}

Soils irrigated from Bani Ghalib canal are assessed for contamination factors (CF), degree of contamination (Cd), modified degree of contamination $(\mathrm{mCd})$ and the pollution load index (PLI). The results are shown in Table (7). It is obvious from these results that $\mathrm{CF}$ values indicated that soils were low (CF) for Fe, Mn, Zn, B, Co, Cr, Ni and Pb; except $\mathrm{Cr}$ and $\mathrm{Ni}$ in winter and summer at Mangabad and Elwan sites respectively. While (CF) was moderate for $\mathrm{Cu}$ and very high for $\mathrm{Cd}$ in all and seasons respectively.

Concerning degree of contamination (Cd) was very high in Arab El Madabegh, Al Hadaya and Gahdam at winter season, while was extremely high degree of contamination in Mangabad and Elwan site at winter. But was extremely high degree of contamination in all sites under studied at summer season.

The ${ }_{\mathrm{m}} \mathrm{Cd}$ suggested that the studied soil showed low degree of $\left({ }_{\mathrm{m}} \mathrm{Cd}\right)$ in all sites at winter season except Mangabad site while in summer season was low degree of contamination at Arab El Madabegh and Hadaya sites. Except for Mangabad, Gahdam and Elwan it was moderate contamination. Pollution load index is used to compare pollution status of different places (Tomlinson et al. 1980). In winter season, the values of PLI was found to be generally (PLI $<1$ ) indicated on perfection in all sites except Mangabad site in winter season ( PLI > 1) indicated on deterioration of this site. While in summer season it showed base line pollution level, as well as at Arab El Madabegh, Gahdam, Elwan and Mangabad. These results confirmed that long term irrigation with polluted water might increase the accumulation of heavy metals in soil.

\section{Enrichment factor (EF) for elements in soils affected by irrigated water from Bani Ghalib at different sites under study.}

A common approach to estimate the anthropogenic impact on soils was to calculate a normalized enrichment factor (EF) for elements concentrations above the uncontaminated background levels. (EF) values of micronutrient elements and heavy metals in the studied area were illustrated in Table 8. Eventually they revealed that (EF) values ranged from 0.1 to 2 and could be considered in the range of natural variability, whereas ratios greater than 2 indicated some enrichment factors corresponding mainly to anthropogenic inputs.

Data in Table (8) showed that, enrichment factor was low for $\mathrm{Mn}, \mathrm{Zn}, \mathrm{B}, \mathrm{Co}, \mathrm{Cr}, \mathrm{Ni}$ and $\mathrm{Pb}$ in all sites and two seasons, except $\mathrm{Mn}, \mathrm{Cr}$ and $\mathrm{Ni}$ at Hadaya site in winter season; $\mathrm{Cr}$ and $\mathrm{Ni}$ in summer season were moderate enrichment factor. Concerning $\mathrm{Cu}$ was low (EF) at Arab El Madabegh and Gahdam in winter and summer seasons. While was high at Hadaya site at winter season and change to moderate (EF) in summer season. As well as (EF) for Cd was high to very high at different sites; $\mathrm{Cd}$ 
Table 7: Contamination Factors, Degree of Contamination, Modified Degree of Contamination and Pollution Load Index in soil irrigated from Bani Ghalib canal at different sites.

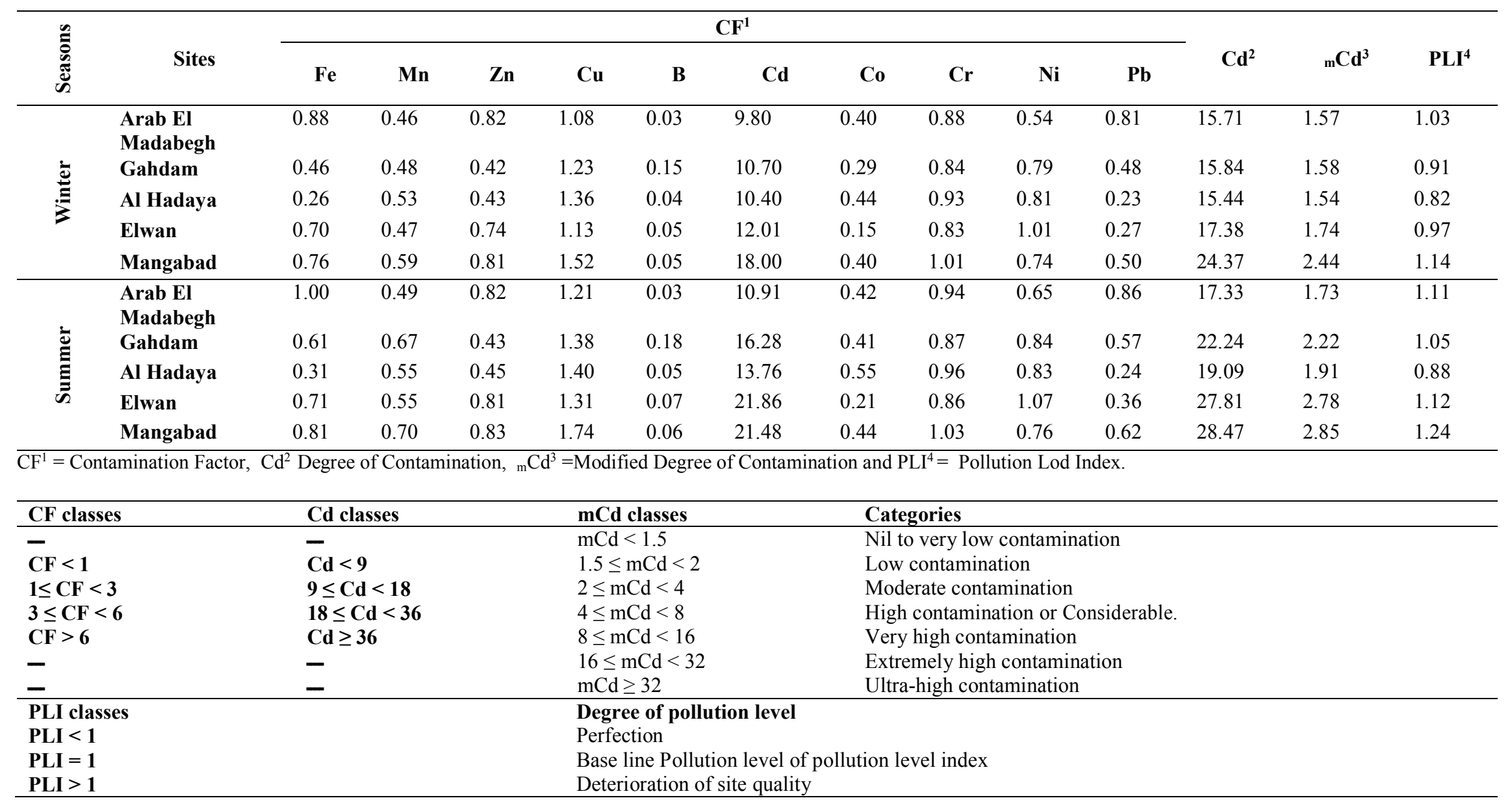


Table 8: Enrichment factors for micro nutrients and heavy metals in soils affected by irrigation of low quality water at different sites.

\begin{tabular}{|c|c|c|c|c|c|c|c|c|c|c|}
\hline \multirow{2}{*}{ 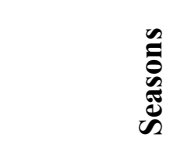 } & \multirow[b]{2}{*}{ Sites } & \multicolumn{9}{|c|}{ Enrichment factor (EF) } \\
\hline & & Mn & Zn & $\mathrm{Cu}$ & B & Cd & Co & $\mathrm{Cr}$ & $\mathbf{N i}$ & $\mathbf{P b}$ \\
\hline \multirow{4}{*}{ 离 } & $\begin{array}{l}\text { Arab El } \\
\text { Madabegh }\end{array}$ & 0.53 & 0.93 & 1.23 & 0.03 & 11.14 & 0.45 & 1.01 & 0.62 & 0.92 \\
\hline & Gahdam & 0.68 & 1.06 & 1.61 & 0.08 & 17.14 & 0.21 & 1.19 & 1.45 & 0.38 \\
\hline & Al Hadaya & 2.02 & 1.61 & 5.15 & 0.17 & 39.40 & 1.67 & 3.53 & 3.08 & 0.85 \\
\hline & Elwan & 0.78 & 1.07 & 2.01 & 0.07 & 23.80 & 0.53 & 1.34 & 0.97 & 0.65 \\
\hline \multirow{5}{*}{$\underset{\Xi}{\bar{\Xi}}$} & $\begin{array}{l}\text { Arab El } \\
\text { Madabegh }\end{array}$ & 0.49 & 0.83 & 1.21 & 0.03 & 10.96 & 0.42 & 0.94 & 0.65 & 0.86 \\
\hline & Gahdam & 0.79 & 1.15 & 1.86 & 0.10 & 30.97 & 0.29 & 1.22 & 1.52 & 0.52 \\
\hline & Al Hadaya & 1.82 & 1.46 & 4.58 & 0.18 & 45.11 & 1.80 & 3.14 & 2.70 & 0.80 \\
\hline & Elwan & 0.87 & 1.03 & 2.14 & 0.07 & 26.49 & 0.54 & 1.27 & 0.94 & 0.77 \\
\hline & Mangabad & 1.10 & 0.71 & 2.27 & 0.30 & 26.82 & 0.68 & 1.44 & 1.38 & 0.94 \\
\hline EF classes & \multicolumn{10}{|c|}{ Degree of contamination level. } \\
\hline $\mathbf{E F}=\mathbf{2 - 5}$ & \multicolumn{10}{|c|}{ Moderate enrichment factor (another source rather than the Earth crust such as human activities). } \\
\hline $\mathbf{E F}=\mathbf{5 - 2 0}$ & \multicolumn{10}{|c|}{ Significant enrichment factor. } \\
\hline $\mathbf{E F}=\mathbf{2 0 - 4 0}$ & \multicolumn{10}{|c|}{ Very high enrichment factor. } \\
\hline $\mathbf{E F}>\mathbf{4 0}$ & \multicolumn{10}{|c|}{ Extremely high enrichment factor. } \\
\hline
\end{tabular}


was high at Arab El Madabegh and Gahdam; while were very high at Mangabad, Hadaya and Elwan in winter season. As well as (EF) for Cd in summer season were high at Arab El Madabegh site, very high at Mangabad, Gahdam and Elwan, but in Al Hadaya was very high. The change Enrichment factor may be due to minerals fertilizer or contamination irrigation water in Bani Ghalib canal. Also this trend indicates that the urban centers contribute to increase elements inputs into the agricultural soils.

The remaining metals negligibly influenced the soil contamination, not exceeding $4 \%$ and decreased in the following order: $\mathrm{Cr}>\mathrm{Zn}>\mathrm{Cu}>\mathrm{Ni}$ (Krzysztof et al. 2004). The significance of EFs values which were outlined by Faiz et al. (2012) indicated generally that $\mathrm{Mn}, \mathrm{Zn}$ and $\mathrm{Cr}$ were deficient to normal enrichment factor (indicates that the predominant source of elements is the earth crust. Moderate enriched most probably from another source rather than the earth crust such as human activities.

Finally and based on the contamination factor, the studied soils were classified as low and slightly contaminated with $\mathrm{Mn}, \mathrm{Zn}, \mathrm{B}, \mathrm{Co}$ and $\mathrm{Pb}$. High to very high contaminated with $\mathrm{Cd}$ and $\mathrm{Cu}$ was low to moderate $(\mathrm{EF})$.

\section{Bio concentration factor (BCF).}

The bioconcentration factor (BCF) refers to the chemical concentration of a substance in an organism's tissue. $\mathrm{BCF}>1$ then the plants can be accumulators; $\mathrm{BCF}=1$ is no influences and $\mathrm{BCF}<$ 1 then the plant can be an excluder.

Data in Table (9) showed that, the bio-concentration was very high $(>1)$ for all plants grown at area and soil affected by polluted irrigation water which considered hyper-accumulator for $(\mathrm{Fe}, \mathrm{Mn}$, $\mathrm{Zn}, \mathrm{Cu}, \mathrm{B}, \mathrm{Cd}, \mathrm{Co} \mathrm{Cr}$ and $\mathrm{Ni}$ ) at winter and summer seasons. Plants may represent an important source of elements for humans as it is well known that metals in soil may be taken up by plants and enter the food chain. The BCF of different plants tissues grow in soil irrigated from Bani Ghalib canal at different sites during winter and summer seasons are presented in Table (9). Data showed that, each plant has specified capability to accumulate elements in their tissue i.e. generally all plants were hyper-accumulator for ( $\mathrm{Fe}, \mathrm{Mn}, \mathrm{Zn}, \mathrm{Cu}, \mathrm{B}, \mathrm{Cd}, \mathrm{Co}, \mathrm{Cr}$ and $\mathrm{Ni}$ ) in all sites at winter and summer seasons, were more than 1 that means bio accumulation plants the adverse plants, except Elephant forage, Okra and Maize with Cd in Arab El Madabegh, Elwan and Mangabad sites at summer were not bio-accumulation plant less than 1. As well as (BCF) for $\mathrm{Pb}$ was less than 1 for Alfa Alfa, Cabbage, Onion, Elephant forage, Eggplant and $\operatorname{BCF}(>1)$ at Wheat, Garlic, Arugula, Okra and Maize plants. This behavior could be attributed to one or more of the following processes: (1) plant adsorb heavy metals, translocate them through tonoplast and accumulate in vacuoles, thereby, protecting cell metabolism from metal toxicity, (2) binding of the cationic element form to the anionic sites in the cell wall (3) binding to non-proteinaceous polypeptides (Phyto 12 chelations) and accumulate in the vacuole Sekar et al. (2004) and Zhu et al. (1999). The advantage of high biomass productive and easy disposal makes plants most useful to remediate heavy metals.

Based on knowledge of the heavy metal accumulation in plants, it is possible to select those species of crops and pasturage herbs, which accumulate fewer heavy metals, for food cultivation and fodder for animals, and to select those hyper accumulation species for extracting heavy metals from soil and water. Sherif et al. (2019) reported that, most plants were considered hyper-accumulator for ( $\mathrm{Fe}, \mathrm{Mn}, \mathrm{Zn}, \mathrm{Cu}, \mathrm{B}, \mathrm{Co}$, and $\mathrm{Cr}$ ); except for $\mathrm{Cd}$ at summer and winter seasons. In summer season; Eggplant fruits with $\mathrm{Co}$; Arugula, Maize with $\mathrm{Ni}$ and $\mathrm{Pb}$; it considered not hyper-accumulator. Concerning winter season; Wheat, Mallow and Onion, considered not hyper-accumulator with $\mathrm{Cu}$, $\mathrm{Cd}, \mathrm{Ni}$ and $\mathrm{Pb}$, this may be due to irrigation water source from Nile River.

The order of bio-accumulation for elements within different plants was as follows:-

Plants that humans feed on: Okra $>$ Arugula $>$ Garlic $>$ Onion $>$ Maize $>$ Cabbage $>$ Eggplant for Fe; Arugula $>$ Okra $>$ Onion $>$ Eggplant $>$ Cabbage $>$ Garlic for Mn; Okra $>$ Garlic $>$ Arugula $>$ Cabbage $>>$ Onion $>$ Eggplant. for $\mathbf{Z n}$; Arugula $>$ Okra $>$ Onion $>$ Cabbage $>$ Garlic $>$ Eggplant for $\mathbf{C u}$; Garlic $>$ Arugula $>$ Onion $>$ Cabbage $>$ Okra $>$ Eggplant for $\mathbf{B}$; Garlic $>$ Onion $>$ Cabbage $>$ Arugula $>$ Eggplant $>$ Okra for Cd; Arugula $>$ Onion $>$ Garlic $>$ Okra $>$ Cabbage $>$ Eggplant for Co; Onion $>$ Arugula $>$ Cabbage $>$ Garlic $>$ Eggplant $>$ Okra for Cr ; Arugula $>$ Okra $>$ Onion $>$ Cabbage $>$ Garlic $>$ Eggplant for Ni and Garlic $>$ Okra $>$ Arugula $>$ Onion $>$ Eggplant $>$ Cabbage for $\mathbf{P b}$. 
Table 9: The BCF of different plants tissues grow in soil irrigated from Bani Ghalib canal at different sites

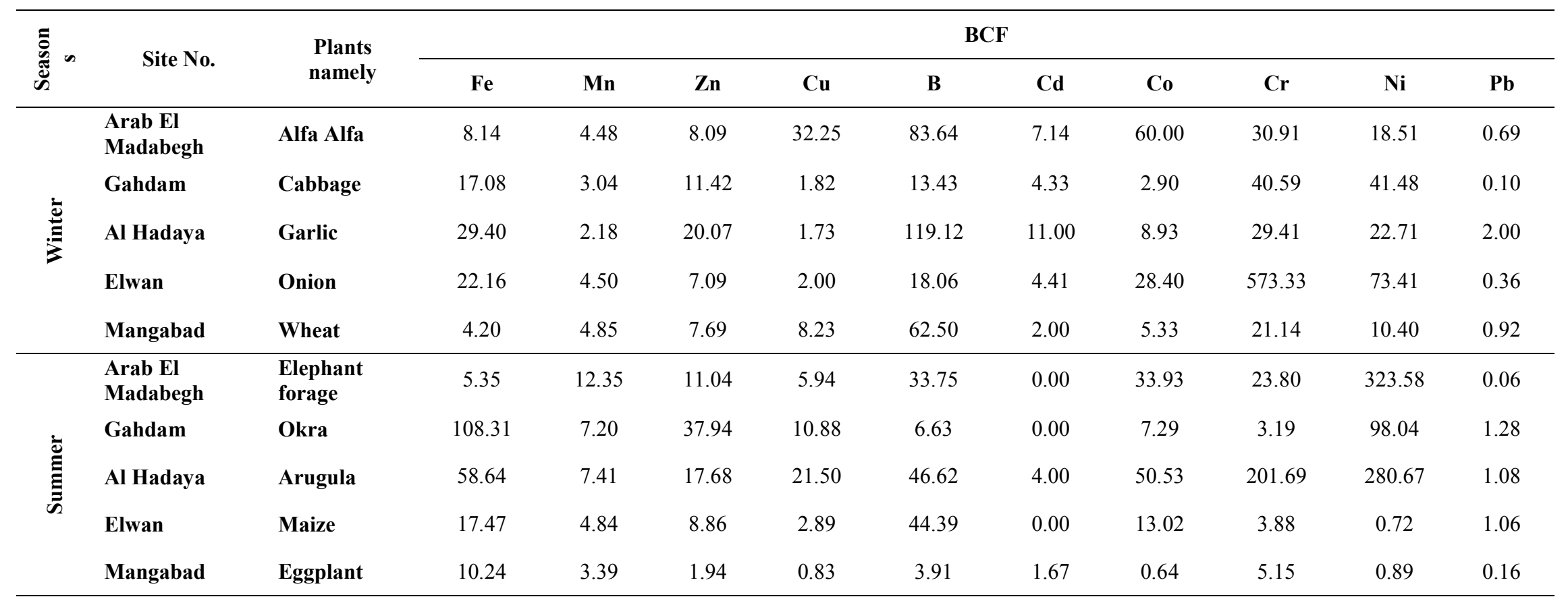


Plants that animals feed on: Maize $>$ Alfa Alfa $>$ Elephant forage $>$ Wheat for Fe; Elephant forage $>$ Wheat $>$ Maize $>$ Alfa Alfa for Mn; Elephant forage $>$ Maize $>$ Alfa Alfa $>$ Wheat for Zn; Alfa Alfa $>$ Wheat $>$ Elephant forage $>$ Maize for Cu; Alfa Alfa $>$ Wheat $>$ Maize $>$ Elephant forage for B; Alfa Alfa $>$ Wheat $>$ Elephant forage $>$ Maize for Cd; Alfa Alfa $>$ Elephant forage $>$ Maize $>$ Wheat for Co; Alfa Alfa $>$ Elephant forage $>$ Wheat $>$ Maize for Cr; Elephant forage $>$ Alfa Alfa $>$ Wheat $>$ Maize for Ni and Maize $>$ Wheat $>$ Alfa Alfa $>$ Elephant forage for $\mathbf{P b}$.

\section{Conclusion and Recommendation:}

The present study demonstrated that some monitoring points of Bani Ghalib canal, showed that heavy metal content in water and soil samples were still below the critical limits. While an increase in some elements from moderate to high in plants. Seasonal variations between seasons contribute pollution load due to mixing of untreated municipal wastes along the course. So, stricter control on sources of pollution. To protect public health, the effluent should either be treated before discharged to the irrigation network or stopping dumping to the canal irrigation water to prevent the pollution and or use with restriction to a certain crop.

\section{References}

Abdel Kawy, W.A.M. 2013. Using GIS modeling to assess the agricultural sustainability in Kafr ElSheikh governorate, Nile Delta, Egypt. Arab J. Geosci., 6:733-747.

Abou El-Anwar, E.A., H. S. Mekky,; W. Abdel Wahab, A.S. Asmoay, A. A. Elnazer and S.A. Salman, 2019. Geochemical characteristics of agricultural soils, Assiut Governorate, Egypt. Bulletin of the National Research Centre, 43(41):1-9.

Abrahim, G. and R. Parker, 2008. Assessment of heavy metal enrichment factors and the degree of contamination in marine sediments from Tamaki Estuary. Auckland, New Zealand. Envir. Monit. and Assess., 136 (1-3): 227 - 238.

Abrahim, G.M.S., 2005. Holocene sediments of Tamaki Estuary, characterization and impact of recent human activity on an urban estuary in Auckland, New Zealand, PhD Thesis Univ. of Auckland: Auckland, New Zealand, 5 - 275.,361.

Adriano, D.C., 1986. Trace elements in the Terrestrial environment. Spring - Verlage.

Alberta, D., 2000. Guidelines for Municipal Wastewater Irrigation Municipal Program Development Branch April.

Alsayed, M.E. and O.E. Negim, 2018. Heavy metals uptake and translocation by lettuce and spinach grown on a metal-contaminated soil. J. of Soil Science and Plant Nutrition, 18 (4): 1097-1107.

American Public Health Association (APHA), 1992. Standard methods for the examination of water and waste water. $18^{\text {th }}$. Washington, D.C, USA.

Association of Official Agriculture Chemists (AOAC), 1995. Method of Analysis. Association of Official Agriculture Chemists. $16^{\text {th }}$ Ed, Washington, D.C, USA.

Awashthi, S.K., 2000. Prevention of food Adulteration Act No.37 of 1954 Central and State rules as amended for 1999 (rd Ed.) New Delhi: Ashoka Law House.

Bennett, W.F., 1993. Nutrient deficiencies and toxicities in crop plants. College of Agric. Sci. Nautural Resources, Texas Tech Univ., Lubbock, Berlin, Heidelberg, New York, 536.

Benton, J. and J. Jones, 2001. Laboratory guide for conducting soil tests and plant analysis.

Bradford, G.R., A.C. Change, A.L. Page, D. Bakhtar, J. A. Frapton and H. Wright, 1996. Background concentrations of Trace and Major Elements in California Soils. Andrew C. Chang, Department of Environmental Sciences University of CA, Riverside, CA 92521, 1-32.

Buat-Menard, P. and R. Chesselet, 1979. Variable influence of the atmospheric flux on the trace metal chemistry of oceanic suspended matter. Earth and Planetary Science Letters. 42 (3): 399-411.

Cottenie, A., M. Varloo, I. Kiekens, G. Velghe, and R. Camerlyneck, 1982. Chemical analysis of plants (Fragaria xanamassa Duch). Plant and Soil, 180: 267-276.

Doneen, L.L., 1954. Salination of soil by salts in the irrigation water. Transansactions, American Geophysical Union. 35(6):943-950.

Eaton, A.D., L.S. Clesceri, E.W. Rice, and A.E. Greenberg, 2005. Standard methods for the examination of water and wastewater, 21st ed., American Public Health Association (APHA), Washington, DC. USA. 
El-Kassas, H.L., S. El- Demerdash, and M.S.A. Dahdoh, 1994. Effect of organic matter and lead interaction on lead status in soil and plants grown in Calcareous soil. Egypt, Soil Sci., 36(1-4): 233-244.

Environmental Protection Agency (EPA), 1991. Methods for the Determination of Metals in Environmental Samples. Office of research and development Washington DC 20460, 23 - 29 and $83-122$.

Environmental Protection Agency (EPA), Guidelines 2007. Regulatory monitoring and testing water and wastewater sampling.

Esawy, K.M. and M.G. Adel, 2016. Effect of polluted water on soil and plant contamination by heavy metals in El-Mahla El-Kobra, Egypt. Solid Earth, 7: 703-711.

Esmat, A. Abou El-Anwar 2019. Assessment of heavy metal pollution in soil and bottom sediment of Upper Egypt: comparison study. Bulletin of the National Research Centre 43(180):1-11.

Faiz, Y., N. Siddique and M. Tufail, 2012. Pollution level and health risk assessment of road dust from an expressway. Journal of Environmental Science and Health, Part A, 47 (6): 818-829.

Food and Agriculture Organization (FAO), 1992. Wastewater Treatment and Use in Agriculture. Irrigation and Drainage Paper 47, FAO, Rome.

Food and Agriculture Organization (FAO), 1985. Water quality for agriculture. Paper No. 29 (Rev. 1) UNESCO, Publication, Rome Italy.

Gerba, C. P., C. Wallis, and J.L. Melnick, 1975. Fate of waste water bacteria and viruses in soil. Journal of the Irrigation Drainage Division, Amer. Soc. of Civil Engineers, 101, 157- 174.

Häkanson, L. 1980. Ecological risk index for aquatic pollution control: Sediment logical approach, Water Res., 14: 975-1001.

International Center for Agricultural Research in the Dry Areas (ICARDA), 2013. Methods of soil, Plant, and water analysis: A manual for the West Asia and North Africa region. Estefan, G., Sommer, R. and Ryan, J. 3th edition. Box 114/5055, Beirut, Lebanon.

Krzysztof, L., W. Danuta, and K. Irena, 2004. Metal contamination of farming soils affected by industry. Environment International 30: 159-165.

Listkas, V.D., V.G. Aschonitis, and V.Z. Antonopulos, 2010. Water Quality in irrigation and Drainage Networks of Thessalonski Plain in Greece Related to Land Use, Water Management, and Agroecosystem Protection. Environ. Monit. Assess. 163:347-359.

Liu, W.H., J.Z. Zhao, Z.Y. Ouyang, L. Soderlund, and G.H. Liu, 2005. Impacts of sewage irrigation on heavy metal distribution and contamination in Beijing, China. Envir. Intern., 31 (6): 805 812.

Liu, W.X., H.H. Li, S.R. Li and Y.W. Wang, 2006. Heavy metal accumulation of edible vegetables cultivated in agricultural soil in the suburb of Zhengzhou City, People's Republic of China. Bulletin of Enviro. Contami. and Toxico, 76: 163-170.

Mekky, H.S., E.A. Abou El-Anwar, S.A. Salman, A.A. Elnazer, W. Abdel Wahab and A.S. Asmoay, 2019. Evaluation of heavy metals pollution by using pollution indices in the soil of Assiut district, Egypt. Egypt. J. Chem., 62(9):1673 - 1683.

Michael, C. A., K.P. O’Neil and C.H. Perry, 2007. Soil vital signs: A new Soil Quality Index (SQI) for assessing forest soil health. Res. Pap. RMRS-RP-65WWW. Fort Collins, CO: U.S. Department of Agriculture, Forest Service, Rocky Mountain Research Station. 12.

Misra, S. G. and D. Mani, 1991. Soil Pollution. Ashish Publishing House, New Delhi, India.

Motsara, M.R. and R.N. Roy, 2008. Guide to laboratory establishment for plant nutrient analysis. Food and Agricultural organization of the United Nations FAO Fertilizer and Plant Nutrition Bulletin Rome.

Muthanna, M.N., 2011. Quality Assessment of Tigris River by Using Water Quality Index for Irrigation Purpose. European Journal of Scientific Research 57:15-28

Qadir, M., D. Wichelns, L. Raschid-Sally, P.S. Minhas, P. Drechsel, A. Bahri, and P. McCornich, 2007. Agricultural Use of Marginal-Quality Water Opportunities and Challenges. IWMI Part, 4:225-226.

Rashed, M.N. 2008. Total and extractable heavy metal in indoor, outdoor and street dust from Aswan City, Egypt. CLEAN- Soil, Air, and Water. 36 (10-11): 850-857. 
Rawway, M., M.S. Kamel, and U.M. Abdul-Raouf, 2016. Microbial and physico-chemical assessment of water quality of the River Nile at Assiut Governorate (Upper Egypt) J. Eco. Heal. Env., 4(1): 7-14.

Richards, L.A., 1954. Diagnosis and improvement of saline and alkaline soils" U.S. Dep. Agric. Hand book 60. U.S.A.

Rocky Mountain Research Station (RMRS), 2012. Sampling procedure for lake or stream surface water chemistry. United State Dep. Agric., Forest Service, Rocky Mountain Research Station, Research Note RMRS- RN- 4. USA.

Rouabhia, A., F. Baali and C. Fehdi 2010. Impact of agricultural activity and lithology on groundwater quality in the Merdja area, Tebessa, Algeria. Arab J. Geosci , 3:307-318.

Sayeda, M.A., Z. Sh. Sabae, M. Fayez, M. Monib and A.N. Hegazi, 2011. The influence of agroindustrial effluents on River Nile pollution. Journal of Advanced Research. 2, 85-95.

Sekar, K.C., N.S. Chary, C.T. Kamala, and Y. Amjaneyulu, 2004. Utilization of plant metal interactions for environmental management. Proceedings of Indian National Science Academy, Part B, Reviews and Tracts Biol. Sci., 70(1):13-30.

Sherif, A.E.A. and A.M. Atwany, 2019. Environmental risks assessment of dust emitted from industrial activities on soil and plants grow. Nature and Acience, 17(10):238-249.

Sherif, A.E.A., E.A. Kishar and Aya A. Taha, 2019. Environmental assessment for soils and plants irrigated from El-Mohett drain. Intern. J. of Environ., 8(1):71-84.

Soltanpour P.N., 1985. Use of ammonium bicarbonate DTPA soil test to evaluate elemental availability and toxicity, Communications in Soil Science and Plant Analysis, 16(3): 323-338.

Soltanpour, P.N., 1991. Determination of nutrient availability element toxicity by AB-DTPA. Soil Test and ICPs. Adv. Soil Sci., 16:165-190.

Tomlinson, D., J. Wilson, C. Harris, and D. Jeffrey, 1980. Problems in the assessment of heavy-metal levels in estuaries and the formation of a pollution index. Helgolander Meeresuntersuchungen, 33 (1- 4): 566 - 575.

Turekian, K.K. and K.H. Wedepohl, 1961. Distribution of elements in some major units of the earth's crust. Geolo. Soc. of Amer., Bulletin, 72: 175-192.

World Health Organization (WHO), 2006. Guidelines for the safe use of wastewater, excreta and greywater / World Health Organization. Volume 2.

Zhu, Y.L., A.A.M. Zayed, J.H. Qian, M. Desoura, and N. Teery, 1999. Phytoaccumulation of trace elements by wetland plants: П. Water hyacinth. J. Environ. Qual. 23: 339-344. 